\title{
In situ NMR studies of the mechanism of homogeneously and heterogeneously catalysed Heck reactions of aryl chlorides and bromides
}

\author{
Vladimir V. Smirnov, ${ }^{\text {a }}$ Sandra S. Pröckl, ${ }^{b}$ Alexander F. Schmidt, ${ }^{\text {a* }}$ and Klaus Köhler ${ }^{b}$ \\ ${ }^{a}$ Department of Chemistry, Irkutsk State University, K. Marx Str. 1, Irkutsk, 664003, Russia \\ ${ }^{b}$ Department of Chemistry, Technische Universität München, Lichtenbergstrasse 4, \\ Garching 85747, Germany \\ E-mail: aschmidt@chem.isu.ru
}

In honor of Prof. Usein M. Dzhemilev

\begin{abstract}
This paper presents for the first time detailed NMR investigations of the changes of the palladium coordination sphere for dissolved $\mathrm{Pd}$ salts $\left(\mathrm{Pd}(\mathrm{OAc})_{2}\right)$ and chosen solid, heterogeneous catalysts $\left(\mathrm{Pd}(\mathrm{II}) / \mathrm{Al}_{2} \mathrm{O}_{3}, \mathrm{Pd}(\mathrm{II}) / \mathrm{NaY}\right.$ zeolite) under Heck reaction conditions for the interesting model substrates bromobenzene and chlorobenzene (and styrene as olefin) using catalytic amounts of $\mathrm{Pd}$ only. The information obtained from the mechanistic studies led us to new optimized simple "ligand free" catalyst systems and reaction conditions that allow the activation of chlorobenzene in an unexpected manner under relatively mild reaction conditions.
\end{abstract}

Keywords: Heck reaction, mechanism, aryl chlorides and bromides, in situ NMR

\section{Introduction}

CC-coupling reactions like Heck reactions (Scheme 1) are of growing interest for organic synthesis and fine chemical industry. Advantages of this reaction are the broad availability of aryl bromides and chlorides and the tolerance of a wide variety of functional groups. An enormous number of new palladium complexes, organometallic compounds and supported Pd catalysts including Pd nanoparticles have been reported for the reaction in the last 10 years (for reviews see e.g. ${ }^{1,2}$ ).<smiles>[R1]C=Cc1ccc([R1])cc1</smiles>

Scheme 1. The Heck reaction. 
Heterogeneous (supported) Pd catalysts have been developed in order to overcome typical problems of catalyst separation and re-use. For long time, supported catalysts showed orders of magnitudes lower activity than soluble Pd complexes or organometallic compounds. Accordingly, typical reports on heterogeneous catalysts focused on aryl iodides and activated aryl bromides as substrates only. In the last few years, however, a number of heterogeneous Pd catalysts have been developed that activate and convert sluggish aryl bromides and aryl chlorides selectively within reaction times of few hours. ${ }^{3}$

The mechanism of the Heck reaction in homogenous solution is widely accepted in a slightly modified form of the original proposal of R.F. Heck. ${ }^{4}$ Nevertheless, some details remain unclear up to now. These concern in particular the very first steps, i.e. the palladium(II) reduction followed by oxidative addition of the aryl halide (Scheme 2). After an intense decade of discussions concerning heterogeneous systems, starting with the work of Schmidt and Mametova, ${ }^{5 \mathrm{a}}$ it seems to be accepted now by most authors that Pd species dissolved (leached) from solid particles into solution are active species in the catalytic cycle of the Heck reaction. That would mean that the majority (or all) important steps of the generally accepted Heck cycle proceed within the coordination sphere of a palladium complex in liquid solution.

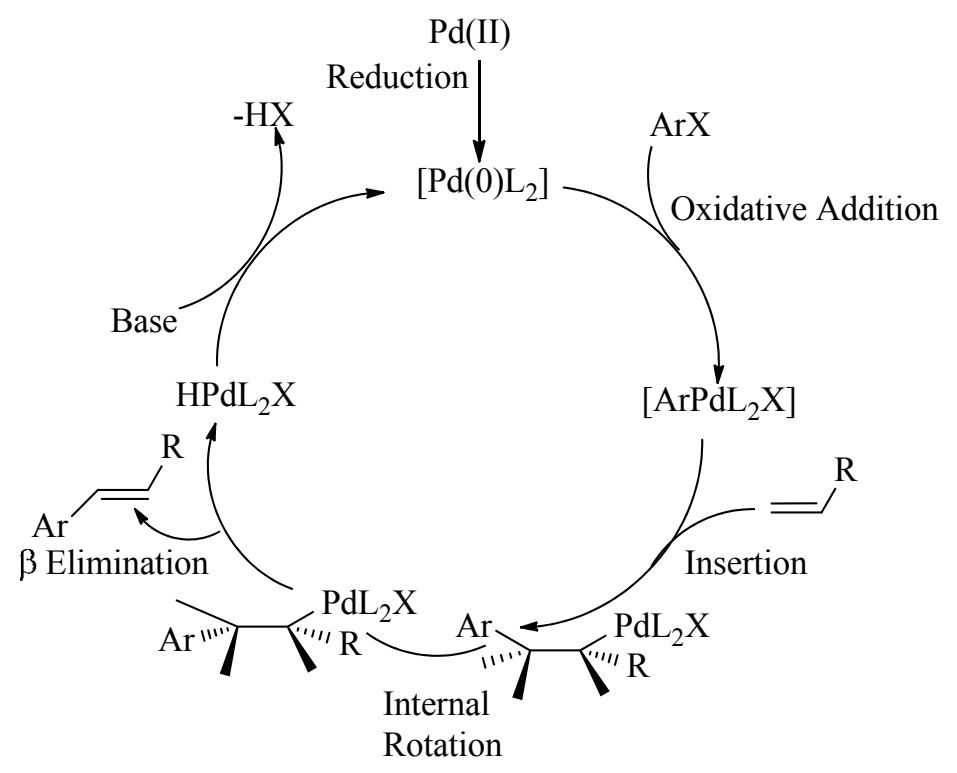

Scheme 2. Postulated Mechanism of the Heck Reaction.

A series of experimental approaches have been reported that confirm this fact. ${ }^{5}$ Up to now, however, no clear experimental results have been reported that describe the immediate dissolution of palladium species from the solid surface of a supported palladium particle. Is this step a physical dissolution of a $\mathrm{Pd}$ atom or complex or is it a chemical reaction (e.g. oxidative addition) belonging directly to the catalytic cycle? Investigations "in situ" under typical reaction conditions are necessary that do not only regard the dissolution itself as done in the reports up to now, but also the changes of the coordination sphere of palladium. Such investigations are of common interest 
because the understanding of this part of the catalytic cycle is still limited for typical homogenous Pd salts and complexes as well as for solid supported Pd systems. Preferentially the investigations comparing homogenous and heterogeneous systems should be performed using the sluggish, but economically and industrially more interesting aryl chlorides and bromides instead of aryl iodides, which have been used nearly exclusively in typical earlier mechanistic studies.

What is an analytical tool that allows monitoring of the changes of palladium coordination sphere under typical reaction conditions for the interesting model substrates bromobenzene and chlorobenzene using catalytic amounts of Pd only? Several attempts lead us to ${ }^{31} \mathrm{P}$ NMR spectroscopy using organophosphorous ligands as "magnetic" probe as the only suitable compromise meeting all demands. Although ${ }^{31} \mathrm{P}$ NMR has been applied before successfully for studies of corresponding Pd phosphane complexes, these investigations were not applied to classical Heck reactions, ${ }^{6}$ used stoichiometric amounts of palladium, ${ }^{7}$ applied aryl iodides as substrates ${ }^{8 a}$ or were limited exclusively to homogenous systems. ${ }^{8 \mathrm{~b}}$

This paper presents for the first time detailed investigations of the changes of the palladium coordination sphere for dissolved $\mathrm{Pd}$ salts $\left(\mathrm{Pd}(\mathrm{OAc})_{2}\right)$ and chosen solid, heterogeneous catalysts $\left(\mathrm{Pd}(\mathrm{II}) / \mathrm{Al}_{2} \mathrm{O}_{3}, \mathrm{Pd}(\mathrm{II}) / \mathrm{NaY}\right.$ zeolite) under reaction conditions for the interesting model substrates bromobenzene and chlorobenzene (and styrene as olefin) using catalytic amounts of Pd only. These experiments and corresponding mechanistic conclusions were possible by ${ }^{31} \mathrm{P}$ NMR studies using triphenylphosphane $\left(\mathrm{PPh}_{3}\right)$ as a probe molecule allowing the detailed identification of the $\mathrm{Pd}$ coordination sphere under reaction conditions. ${ }^{6 a, 8 a}$ The only limiting problem - the possible intervention of the probe molecule $\mathrm{PPh}_{3}$ in the catalytic cycle - could be excluded by the combination of various experimental conditions including in situ experiments, Pd leaching experiments as a function of aryl halide conversion and several "blank tests". The information obtained from the mechanistic studies led us to new optimized simple "ligand free" catalyst systems and reaction conditions that allow the activation of chlorobenzene in an unexpected manner.

\section{Results and Discussion}

As argued in the introduction the use of triphenylphosphane as ${ }^{31} \mathrm{P}$ NMR probe can give us valuable "in situ" information about the reaction mechanism of the Heck reaction in homogeneous as well as heterogeneous catalyst systems. One can expect structural information on intermediate species and separate the homogeneously dissolved Pd species from surface species (the latter ones are not detectable by such NMR experiments) at the same time. The choice of the most active heterogeneous catalyst systems known to date $\left(\mathrm{Pd}(\mathrm{II}) / \mathrm{Al}_{2} \mathrm{O}_{3},\left[\mathrm{Pd}\left(\mathrm{NH}_{3}\right)_{4}\right]^{2+} / \mathrm{NaY}\right.$ zeolite) allows the investigation of interesting substrates i.e. bromo and chloro benzene in mechanistic studies for the first time.

On the other hand the presence of organophosphorous ligands in the system may undoubtedly influence the proceeding of the reaction and the activity of the Pd species in solution. In case of supported Pd catalysts the dissolution (leaching) of Pd from the support can be influenced. The latter process is one of the most crucial problems discussed in the literature in the last few years. 
Therefore a series of investigations about the $\mathrm{PPh}_{3}$ influence on catalysis have been carried out first and this section has been structured as follows:

1. The Effect of $\mathrm{PPh}_{3}$ on the Heck reaction of bromobenzene or chlorobenzene with styrene using classical homogeneous $\left(\mathrm{Pd}(\mathrm{OAc})_{2}\right)$ and heterogeneous catalysts $\left(\mathrm{Pd}(\mathrm{II}) / \mathrm{Al}_{2} \mathrm{O}_{3}, \mathrm{Pd}(\mathrm{II}) /\right.$ zeolite $\left.\mathrm{Y}\right)$, respectively, have been studied by catalytic experiments (conversion and yields as function of reaction time).

2. The influence of $\mathrm{PPh}_{3}$ on the leaching of Pd from the support into solution has been investigated as function of temperature, conversion / catalytic activity and reaction time.

3. ${ }^{31} \mathrm{P}$ NMR chemical shifts were taken and interpreted for all $\mathrm{Pd}$ complexes expected under various conditions in solution during the reaction.

4. ${ }^{31} \mathrm{P}$ NMR studies have been performed during the Heck reaction of the aryl halides $(\mathrm{PhBr}, \mathrm{PhCl})$ with styrene at varying temperatures with $\mathrm{Pd}(\mathrm{OAc})_{2}$ and supported $\mathrm{Pd}$ systems in typical reaction mixtures (NMP as solvent, base, additives). In order to eliminate possible influences of the phosphane all measurements were carried out by three different methods:

(a) Two $\mathrm{PPh}_{3}$ equivalents were added to the reaction mixture at the beginning of the reaction. At fixed periods of the time the reaction was interrupted and NMR spectra were recorded.

(b) The reaction was performed in the absence of phosphane. Phosphane was added to the reaction mixture after fast quenching of the reaction mixture just before recording the NMR spectra. Due to the strong coordination of $\mathrm{PPh}_{3}$ to $\mathrm{Pd}$ one could expect that the $\mathrm{Pd}$ phosphane complexes form in the solution very fast.

(c) The experiments were carried out directly in the NMR tube as in situ monitoring of the reaction.

The palladium complexes formed in solution during the reactions are identical in presence as well as absence of $\mathrm{PPh}_{3}$ in all systems investigated in all cases a-c indicating that $\mathrm{PPh}_{3}$ does not have a significant effect on the reaction mechanism.

5. Finally, catalytic experiments were performed under optimized reaction conditions (control of activity by reactant concentration and reducing/oxidizing agents) that have been concluded from the present mechanistic investigations and that additionally verify the corresponding interpretations.

\section{Effect of $\mathrm{PPh}_{3}$ on the catalytic activity in the Heck reaction}

The yield of trans-stilbene in the Heck reaction of $\mathrm{PhBr}$ and styrene using $\mathrm{Pd}(\mathrm{OAc})_{2}$ as catalyst as a function of reaction time is shown in Figure 1a. As expected, the presence of $\mathrm{PPh}_{3}$ has a beneficial effect on this homogeneously catalyzed Heck reaction. In absence of $\mathrm{PPh}_{3}$ the deactivation of the catalyst due to $\mathrm{Pd}$ aggregation (Pd black formation) causes interruption of stilbene formation already after $100 \mathrm{~min}$. (Figure 1a). In contrast, Pd stabilization in the solution by the complexation by triphenylphosphane allows complete transformation of bromobenzene into Heck reaction products after few hours (Figure 1a). A measurable conversion can be observed at temperatures of $140{ }^{\circ} \mathrm{C}$ and above in both cases. Chlorobenzene is not converted at all under these conditions as known from numerous literature reports. 


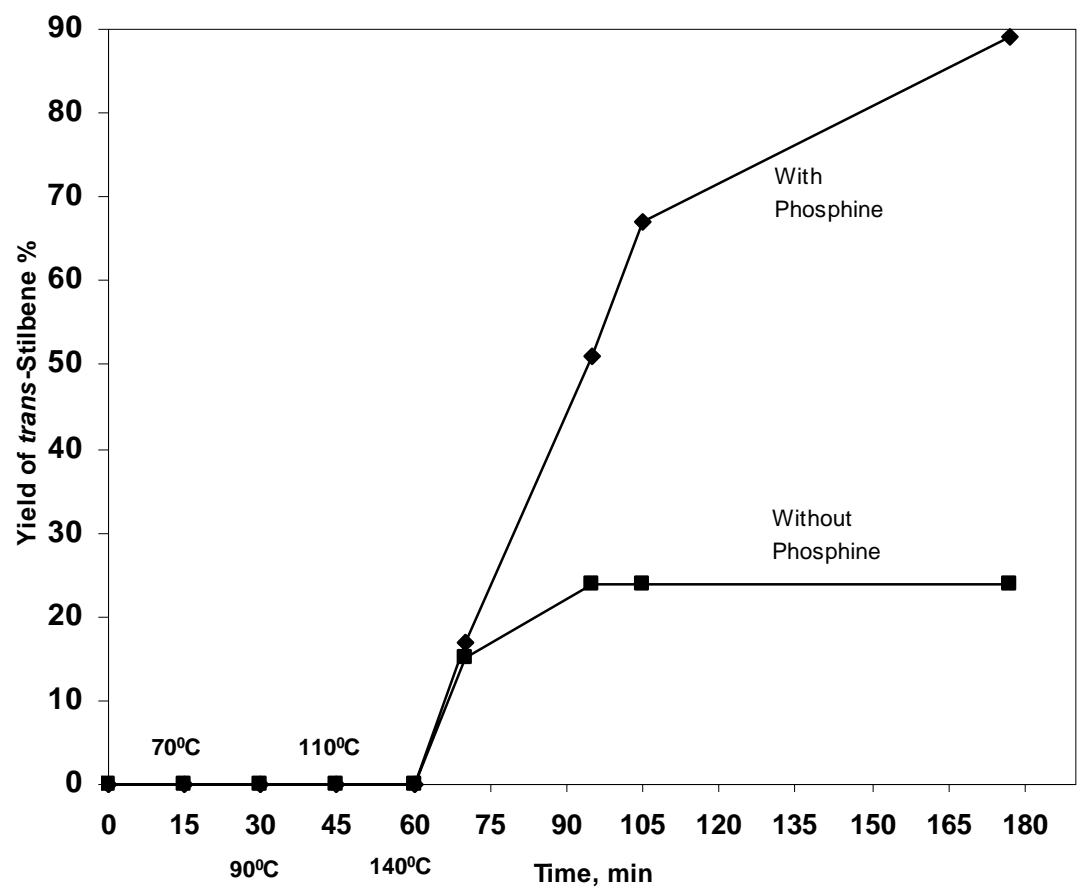

Figure 1a. Heck Reaction of $\mathrm{PhBr}$ with Styrene, $\mathrm{Pd}(\mathrm{OAc})_{2}$, $\mathrm{AcONa}, 70-140{ }^{\circ} \mathrm{C}$

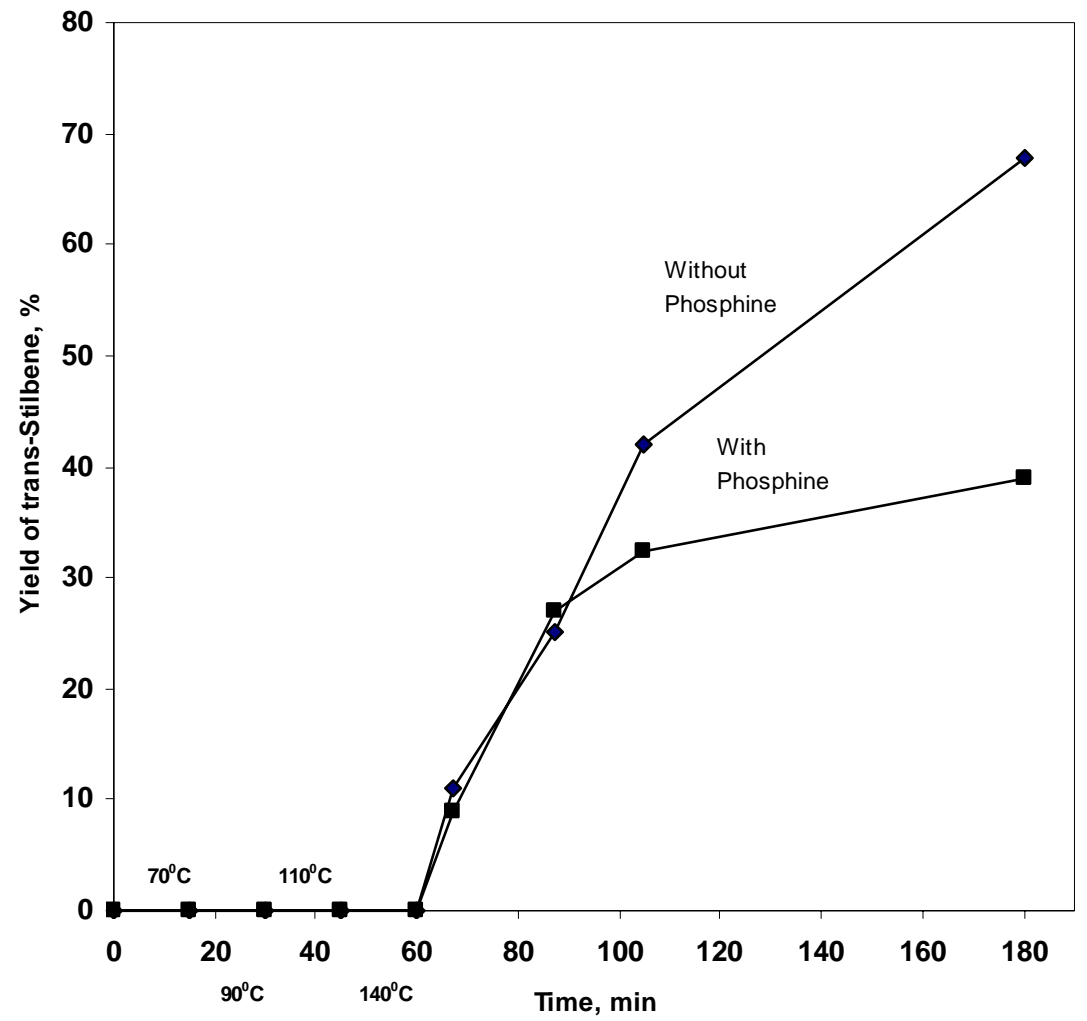

Figure 1b. Heck Reaction of $\mathrm{PhBr}$ with Styrene, $\mathrm{Pd}(\mathrm{II}) / \mathrm{Al}_{2} \mathrm{O}_{3}, \mathrm{AcONa}, 70-140{ }^{\circ} \mathrm{C}$. 
The effect of two equivalents $\mathrm{PPh}_{3}$ on the activity in Heck reactions of $\mathrm{PhBr}$ and $\mathrm{PhCl}$ with heterogeneous catalysts is less obvious (Figures 1b,1c). These investigations were only possible using some of the most active heterogeneous catalyst systems reported $\left(\mathrm{Pd}(\mathrm{II}) / \mathrm{Al}_{2} \mathrm{O}_{3}\right.$, $\mathrm{Pd}(\mathrm{II}) / \mathrm{NaY}){ }^{3 \mathrm{a}, \mathrm{b}}$ The most active catalyst system - Pd incorporated into zeolite $\mathrm{Y}$ (and addition of $\mathrm{Bu}_{4} \mathrm{NBr}$ ) - has been chosen in order to achieve the difficult activation of chlorobenzene. The reaction in the presence of $\mathrm{PPh}_{3}$ is retarded in comparison to the phosphine-free experiment for all substrates and solid catalysts used. The reactions are not complete and the conversion of the initial components is found to be analogous to the experiments without $\mathrm{PPh}_{3}$. The reduction of the reaction rate by triphenylphosphane can be explained by a reduced number of free coordination sites at the $\mathrm{Pd}$ center (coordination of $\mathrm{PPh}_{3}$; see later).

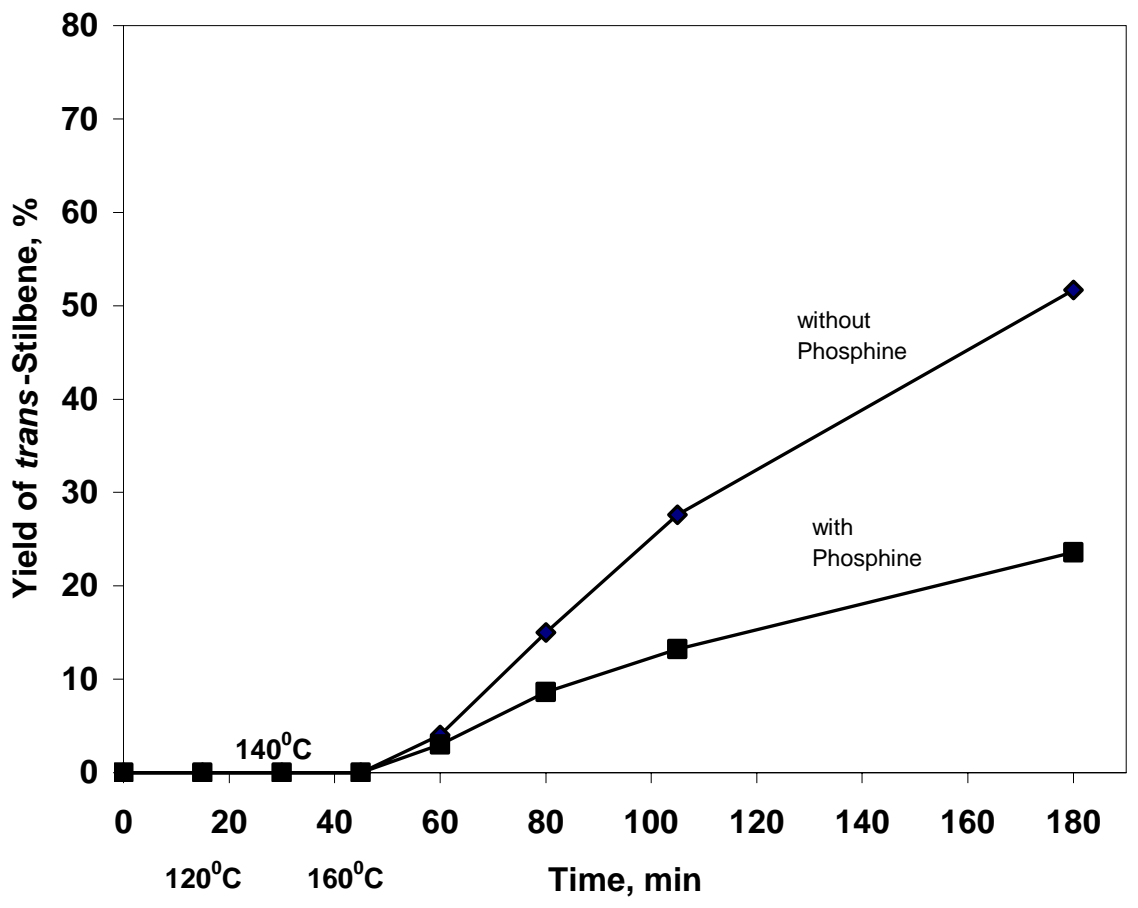

Figure 1c. Heck Reaction of $\mathrm{PhCl}$ with Styrene, $\mathrm{Pd}(\mathrm{II}) / \mathrm{NaY}, \mathrm{Ca}(\mathrm{OH})_{2}, \mathrm{NBu} 4 \mathrm{Br}, 120-160{ }^{\circ} \mathrm{C}$.

\section{Effect of $\mathrm{PPh}_{3}$ on the leaching of Pd from the support}

Figure 2 illustrates a typical course of the Pd concentration in solution during the Heck reaction of bromobenzene with styrene catalyzed by $\mathrm{Pd}(\mathrm{II}) / \mathrm{Al}_{2} \mathrm{O}_{3}$ in presence and absence of $\mathrm{PPh}_{3}$ (determined by atomic absorption spectroscopy, see experimental). In the absence of $\mathrm{PPh}_{3}$, reaction and dissolution of $\mathrm{Pd}$ from the support have been observed only at a temperature of $140{ }^{\circ} \mathrm{C}$ (after 20 min. of slow temperature increase by about $2 \mathrm{~K}$ per min. in this experiment, Figure 2). The maximum $\mathrm{Pd}$ concentration in solution is observed after about 30 minutes that corresponded to the highest reaction rate. Analogous experiments have been reported in the literature for other heterogeneous catalysts for aryl bromides as well as aryl chlorides. ${ }^{3 a, b}$ At the end of the reaction 
(when the aryl bromide is converted), palladium was completely re-deposited onto the support. In contrast, the Pd content in solution raised continuously until palladium was completely dissolved from the surface of the support when two equivalents of $\mathrm{PPh}_{3}$ were present (Figure 2). Note that $\mathrm{Pd}$ dissolves already at temperatures below $100^{\circ} \mathrm{C}$ (i.e. clearly below reaction temperature) and that the overall $\mathrm{Pd}$ concentration is substantially higher (100\% of the total $\mathrm{Pd}$ amount in the system) than in the absence of $\mathrm{PPh}_{3}$.

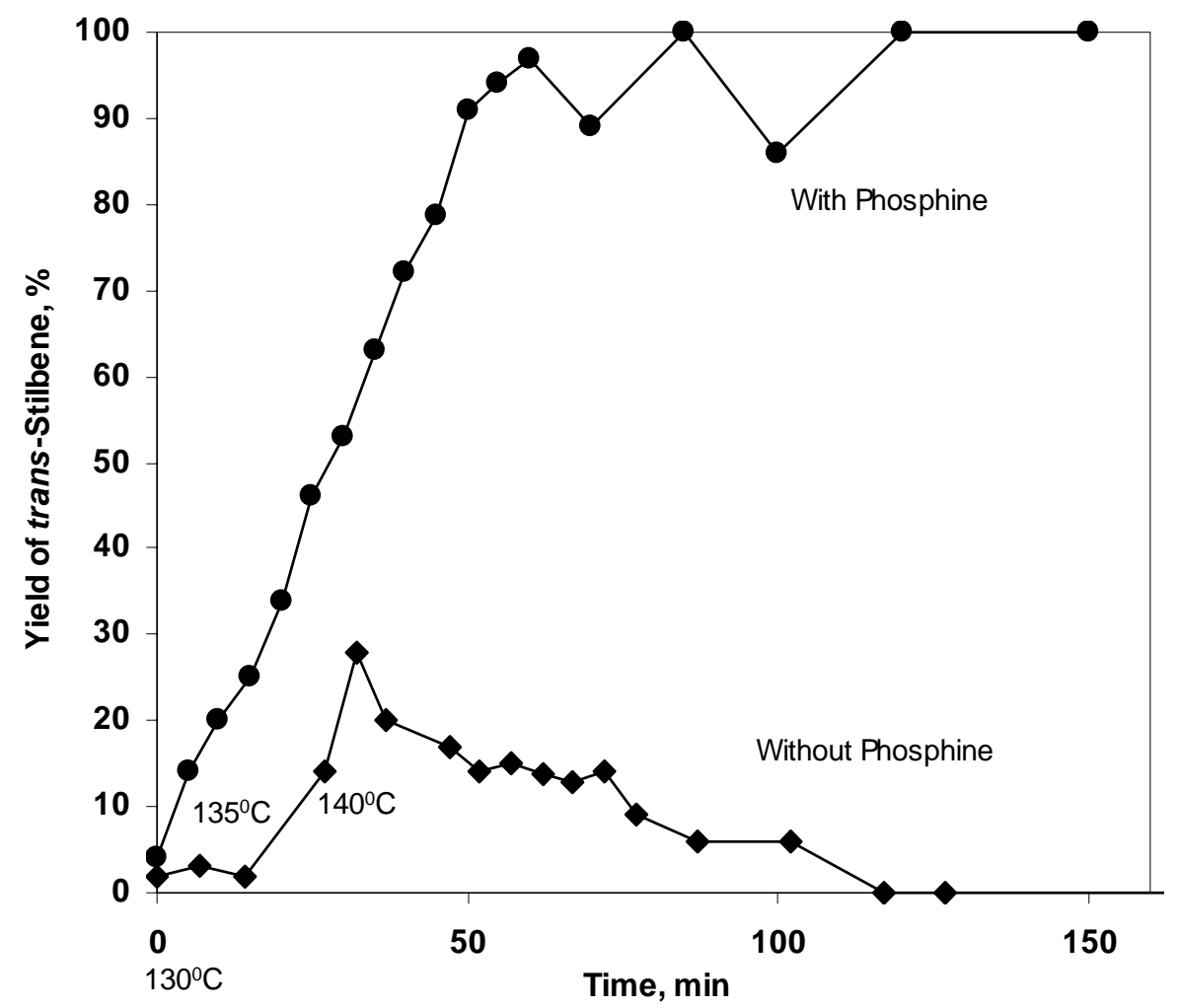

Figure 2. Influence of the addition of $\mathrm{PPh}_{3}$ on the $\mathrm{Pd}$ Leaching in the Heck reaction of bromobenzene and styrene.

It is important to note that the selectivity of the Heck reaction to the products have been independent of the presence or absence of $\mathrm{PPh}_{3}$ in all systems studied (Figure 1). This indicates similar or identical catalytic cycles in both cases. Based on measurements by NMR and of kinetic isotope effects for homogeneous systems (with and without $\mathrm{PPh}_{3}$ ), it has been demonstrated recently that the addition of phosphane does not change the nature and reactivity of those intermediates of the catalytic cycle that make the main contribution to the catalytic reaction. Although smaller differences in process kinetics have been observed during the reaction, conclusions concerning the reaction mechanism drawn from ${ }^{31} \mathrm{P}$ NMR experiments with $\mathrm{PPh}_{3}$ can thus be extended to the phosphane-free reaction systems. 


\section{${ }^{31} P$ NMR chemical shifts of Pd complexes}

The chemical shifts of all intermediate complexes imaginable and expected during the Heck reaction according to the classic mechanism were determined in separate experiments (see Experimental section). All relevant data and the corresponding assignments of the NMR signals are summarized in Scheme 3. The reversible exchange of chloride, bromide and acetate ligands at the central atom Pd were observed upon addition of a 30-fold excess of appropriate salts (Scheme 3) by the change of respective chemical shifts in the spectra.

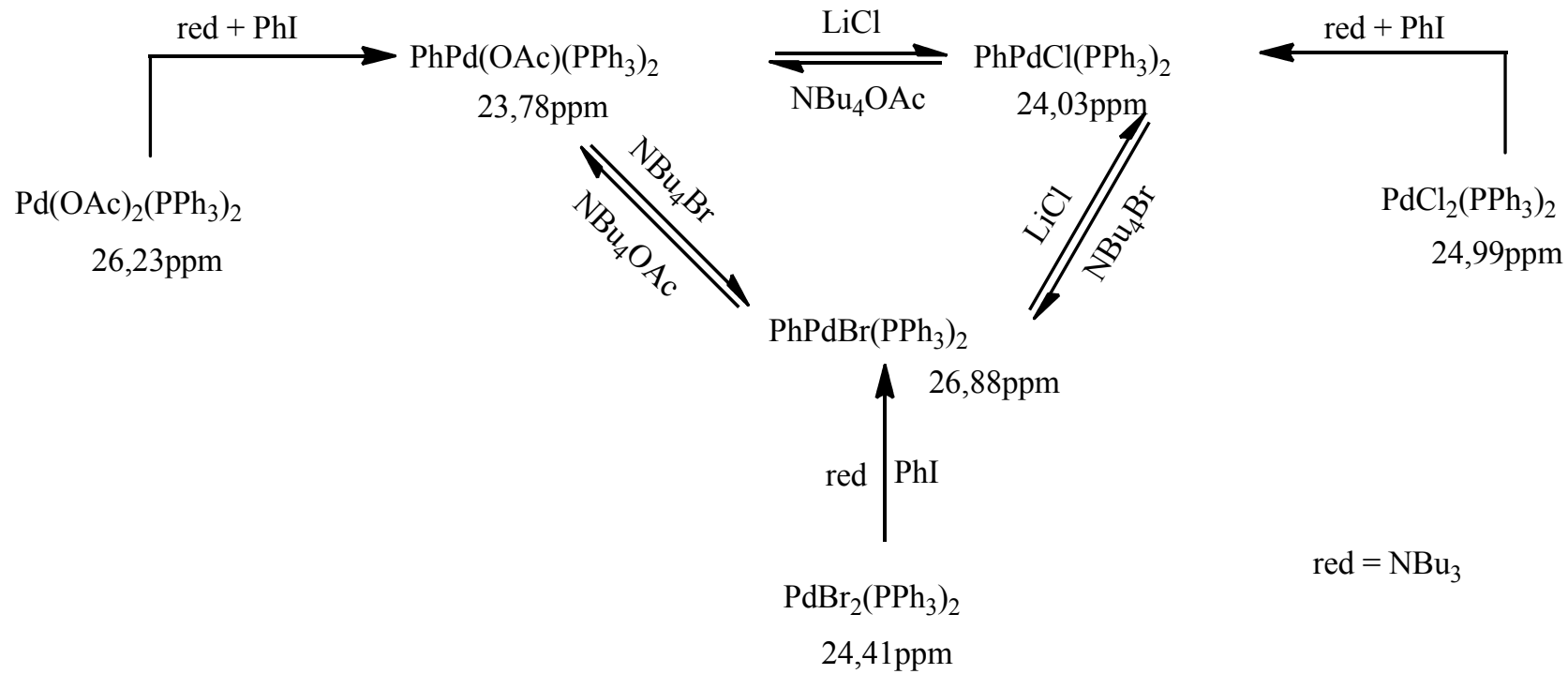

Scheme 3. The formation, chemical shifts, and reactions of palladium phosphine complexes.

\section{${ }^{31} \mathrm{P}$ NMR studies during the Heck reaction of $\mathrm{PhBr}$ and $\mathrm{PhCl}$ with styrene \\ Reaction of $\mathrm{PhBr}$ with styrene catalyzed by $\mathrm{Pd}(\mathrm{OAc})_{2}$ and $\mathrm{Pd}(\mathrm{II}) / \mathrm{Al}_{2} \mathrm{O}_{3}$. These classical} homogeneous and heterogeneous catalysts have been chosen for the study of the Pd coordination sphere in the bromobenzene reaction with styrene because it is known that both $\operatorname{Pd}(\mathrm{OAc})_{2}{ }^{11 \mathrm{a}}$ and $\mathrm{Pd}(\mathrm{II}) / \mathrm{Al}_{2} \mathrm{O}_{3}{ }^{3 \mathrm{a}, \mathrm{b}}$ successfully catalyze the model reaction quite well. Monitoring of the reaction by ${ }^{31} \mathrm{P}$ NMR according to the three methods described above (4a-c) gave identical results. No qualitative differences have been found between homogeneous $\mathrm{Pd}(\mathrm{OAc})_{2}$ and heterogeneous $\mathrm{Pd}(\mathrm{II}) / \mathrm{Al}_{2} \mathrm{O}_{3}$ catalysts. Figure 3 represents a succession of the recorded NMR spectra for different reaction times and temperatures $\left(70^{\circ} \mathrm{C}\right.$ to $\left.140{ }^{\circ} \mathrm{C}\right)$, when bromobenzene reacts directly with styrene in the NMR tube. Unreduced $\mathrm{Pd}(\mathrm{II}) / \mathrm{Al}_{2} \mathrm{O}_{3}$ was used as the heterogeneous catalyst and sodium acetate as base. First, the signal of free $\mathrm{PPh}_{3}\left(70{ }^{0} \mathrm{C}\right.$, signal a) in solution was observed. With rising temperature a signal of the complex $\left[\mathrm{Pd}(\mathrm{OAc})_{2}\left(\mathrm{PPh}_{3}\right)_{2}\right]\left(90-110{ }^{\circ} \mathrm{C}\right.$, signal b) appeared. The signal of the product of oxidative addition with one coordinating $\mathrm{OAc}^{-}$ion, $\left[\mathrm{Pd}(\mathrm{OAc})(\mathrm{Ph})\left(\mathrm{PPh}_{3}\right)_{2}\right]$, did not appear until $\mathrm{T}=140{ }^{\circ} \mathrm{C}$ (Figure 3, signal c).

Since bromide ions are formed in the catalytic cycle, the gradual transformation of $\mathrm{Pd}$ acetato complexes into bromo complexes $\left[\mathrm{Pd}(\mathrm{Br})(\mathrm{Ph})\left(\mathrm{PPh}_{3}\right)_{2}\right]$ (Figure 3, signal d) occurred. It appeared at about $30 \%$ of bromobenzene conversion and was observable until the displacement of acetate ions 
by $\mathrm{Br}^{-}$in the coordination sphere of $\mathrm{Pd}(\mathrm{II})$ was complete. After 150 minutes reaction time the complex $\left[\mathrm{Pd}(\mathrm{Br})(\mathrm{Ph})\left(\mathrm{PPh}_{3}\right)_{2}\right]$ complex was observed together with $\mathrm{PdBr}_{2}\left(\mathrm{PPh}_{3}\right)_{2}$. This indicates the a side reaction probably to biphenyl formation (accompanied by formation of $\left[\mathrm{PdBr}_{2}\left(\mathrm{PPh}_{3}\right)_{2}\right]$ outside of the Heck cycle and indicating catalyst deactivation). ${ }^{2 \mathrm{a}, 11 \mathrm{~d}}$ The problem of continued oxidation of active $\operatorname{Pd}(0)$ species can be solved by addition of catalytic quantities of reducing agents. $^{9,11 \mathrm{~b}, \mathrm{~d}}$

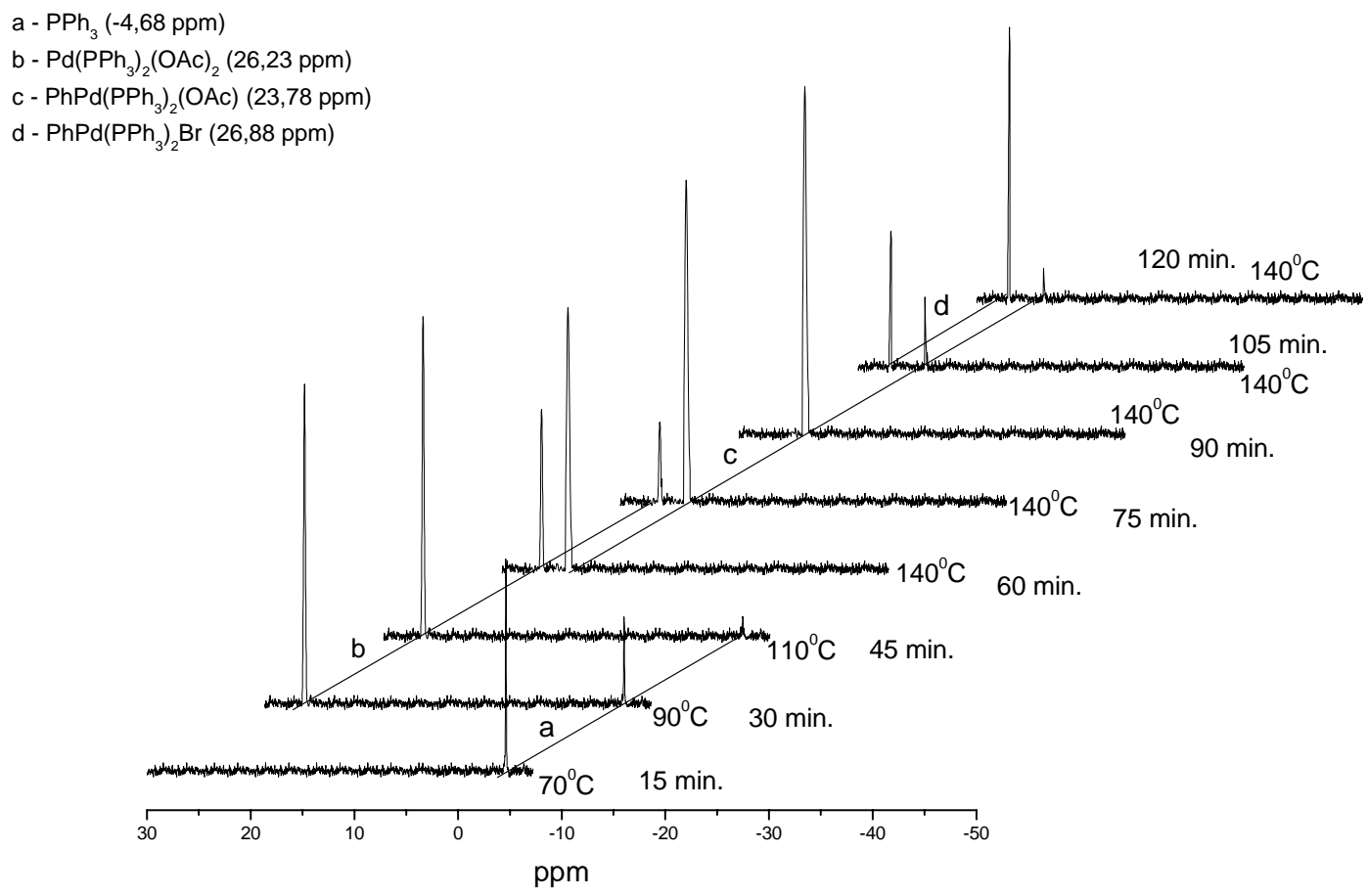

Figure 3. ${ }^{31} \mathrm{P}$ NMR spectra recorded in the course of $\mathrm{PhBr}$ reaction with styrene, $\mathrm{Pd}(\mathrm{II}) / \mathrm{Al}_{2} \mathrm{O}_{3}$, AcONa, $70-140{ }^{\circ} \mathrm{C}$.

The investigations show that all species in homogeneous und heterogoneous systems are identical in the presence and absence of $\mathrm{PPh}_{3}$. The temperature dependence of palladium leaching into solution is, however, different for both experiments. Whereas Pd leaching has been supported by $\mathrm{PPh}_{3}$ already at temperatures of $90-110^{\circ} \mathrm{C}$ (Figure 2,3), $\mathrm{Pd}$ leaching is observed at $140^{\circ} \mathrm{C}$ only in the absence of phosphane (Figure 2), i.e. at that temperature, where oxidative addition of the aryl halide has first been indicated by Heck product formation (and in situ NMR, see later).

Reaction of $\mathrm{PhCl}$ with styrene catalyzed by $\mathbf{P d}(\mathbf{I I}) / \mathrm{NaY}$. As in the reaction between bromobenzene and styrene, the first signal in the NMR spectrum (Figure 4, signal a) has been the one of free $\mathrm{PPh}_{3}\left(90-120{ }^{\circ} \mathrm{C}\right)$. At $\mathrm{T}=140{ }^{\circ} \mathrm{C}$, the NMR spectrum of complex $\left[\mathrm{PdBr}_{2}\left(\mathrm{PPh}_{3}\right)_{2}\right]$ (Figure 4, signal b) appeared as a result of $\mathrm{Pd}$ leaching unlike the previous case $(\mathrm{PhBr})$, where the $\mathrm{Pd}^{2+}$ complex with acetate ligand was observed. Different additives and bases used in the catalytic systems are responsible for that. In the Heck reaction with bromobenzene, AcONa was used as base instead of $\mathrm{Ca}(\mathrm{OH})_{2}$ in the present case. The latter one was found to be the only base allowing an 
effective conversion of $\mathrm{PhCl}$ (despite of its low solubility in NMP). ${ }^{3 \mathrm{a}, \mathrm{b}}$ The formation of the bromo complex is explained by the presence of $\mathrm{NBu}_{4} \mathrm{Br}$ (excess) in solution, the addition of which represents another necessary condition for the chlorobenzene conversion into stilbene. ${ }^{3 \mathrm{a}, \mathrm{b}}$
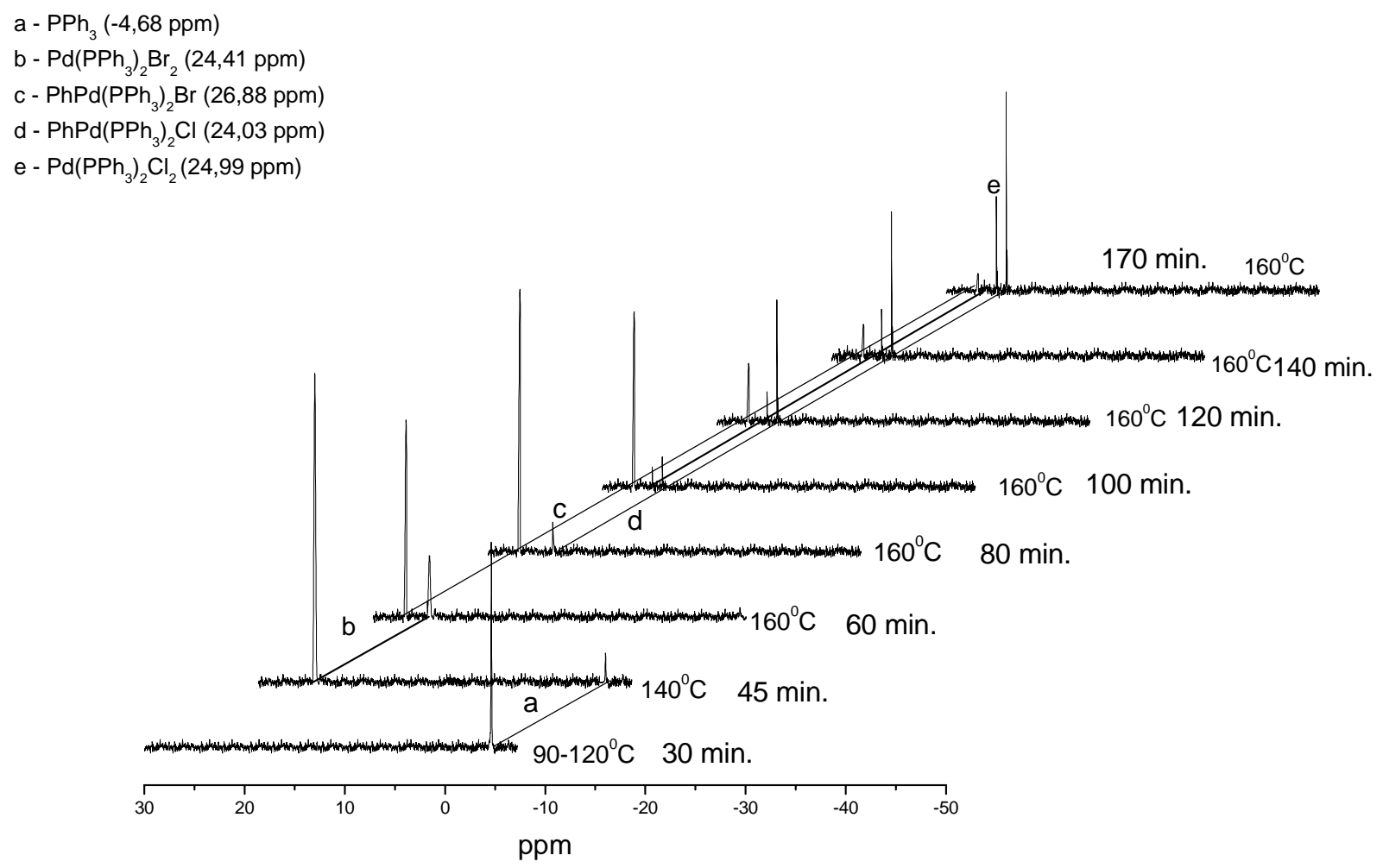

Figure 4. ${ }^{31} \mathrm{P}$ NMR spectra recorded in the course of $\mathrm{PhCl}$ reaction with styrene, $\mathrm{Pd}(\mathrm{II}) / \mathrm{NaY}$, $\mathrm{Ca}(\mathrm{OH})_{2}, \mathrm{NBu}_{4} \mathrm{Br}, 90-160{ }^{\circ} \mathrm{C}$.

Further heating of the reaction mixture led to the appearance of the oxidative addition product $\left[\mathrm{Pd}(\mathrm{Br})(\mathrm{Ph})\left(\mathrm{PPh}_{3}\right)_{2}\right]$ at $\mathrm{T}=160{ }^{\circ} \mathrm{C}$ (Figure 4, signal c). This temperature is consistent with the catalytic experiments $^{3 \mathrm{a}, \mathrm{b}}$, where the reaction starts efficiently only at $\mathrm{T}=160{ }^{\circ} \mathrm{C}$ as well. With increasing conversion of chlorobenzene, a gradual substitution of bromide by chloride ions occurred in $\left[\mathrm{Pd}(\mathrm{Br})(\mathrm{Ph})\left(\mathrm{PPh}_{3}\right)_{2}\right]$ giving $\left[\mathrm{Pd}(\mathrm{Cl})(\mathrm{Ph})\left(\mathrm{PPh}_{3}\right)_{2}\right]($ Figure 4, signal d). The presence of oxidized $\mathrm{Pd}$ in solution as $\left[\mathrm{PdCl}_{2}\left(\mathrm{PPh}_{3}\right)_{2}\right]$ (Figure 4, signal e) during the whole reaction is an obvious difference between the reactions of $\mathrm{PhBr}$ and $\mathrm{PhCl}$. In addition it must be mentioned that the phenomenon " $\mathrm{Pd}$ leaching" has a somewhat different meaning in the case of the zeolite supported Pd complexes: it does not concern the split off of a $\mathrm{Pd}$ atom from a solid palladium particle (as in the case of $\left.\mathrm{Pd} / \mathrm{Al}_{2} \mathrm{O}_{3}\right)$ but the leaving out of a dissolved encapsulated $\mathrm{Pd}$ complex $\left(\left[\mathrm{Pd}\left(\mathrm{NH}_{3}\right)_{4}{ }^{2+}\right]\right)$ from the pores of the zeolite into bulk solution. That means that the reaction takes place outside the zeolite pores and the zeolite represents a reservoir for dissolved active Pd species only. 


\section{Discussion of the combined in situ NMR and leaching investigations}

The above results allow the major conclusions to be made on the mechanism of the Heck reaction in the presence of heterogeneous catalysts. It has been established that Pd leaching from catalyst surface initiates progress of the catalytic reaction. That conclusion is based on the data from NMR monitoring and GLC analysis that an appearance of the oxidative addition product in the solution and the beginning of the catalytic reaction occur simultaneously. Homogeneous nature of the "heterogeneously" catalyzed Heck reaction is corroborated by the identical monitoring results of the reactions in the presence of both homogeneous $\left(\mathrm{Pd}(\mathrm{OAc})_{2}\right)$ and heterogeneous $\left(\mathrm{Pd}(\mathrm{II}) / \mathrm{Al}_{2} \mathrm{O}_{3}\right.$, $\mathrm{Pd}(\mathrm{II}) / \mathrm{NaY})$ catalysts.

In this connection the reasons for the high efficiency of unreduced heterogeneous catalysts in Heck reaction with unreactive aryl halogenides in comparison with their reduced analogues (previously used ${ }^{5 \mathrm{a}, \mathrm{b}, \mathrm{c}}$ ) become understandable. As shown in the literature, ${ }^{5 \mathrm{a}}$ the most probable reason for the Pd leaching from the surface of reduced $\mathrm{Pd}(0) / \mathrm{C}$ is $\mathrm{Pd}$ oxidation by aryl halides in presence of appropriate ligands (halide anions, $\mathrm{PPh}_{3}$ ) in the stage of oxidative addition, which is made difficult by a drastically decrease of the reactivity in the order $\mathrm{ArI}>\mathrm{ArBr}>>\mathrm{ArCl}$. This problem is solved by the application of unreduced heterogeneous $\left(\mathrm{Pd}(\mathrm{II}) / \mathrm{Al}_{2} \mathrm{O}_{3}\right.$ and $\left.\mathrm{Pd}(\mathrm{II}) / \mathrm{NaY}\right)$ catalyst in presence $\mathrm{NaOAc}$ or $\mathrm{NBu}_{4} \mathrm{Br}$ that increases Pd leaching and therefore, activity. It is corroborated by the initial appearance of $\mathrm{PdX}_{2}\left(\mathrm{PPh}_{3}\right)_{2}(\mathrm{X}=\mathrm{OAc}$ or $\mathrm{Br})$ complexes in the solution and only after that the oxidative addition product $\left[\mathrm{Pd}(\mathrm{X})(\mathrm{Ph})\left(\mathrm{PPh}_{3}\right)_{2}\right]$.

The triphenylphosphane role in this process can be quite important. The powerful coordinative capability of triphenylphosphane to $\mathrm{Pd}$ may favor the fast complexation and as result $\mathrm{Pd}$ leaching (Figure 2). The necessary temperature for $\mathrm{Pd}$ leaching with $\mathrm{PPh}_{3}$ was $90-120{ }^{\circ} \mathrm{C}$ under studied conditions but the Heck reaction was limited by oxidative addition stage $\left(140{ }^{\circ} \mathrm{C}\right.$ for bromobenzene and $160^{\circ} \mathrm{C}$ for chlorobenzene). Note, that $\mathrm{Pd}$ going into solution in a form of $\operatorname{Pd}\left(\mathrm{X}_{2}\right)\left(\mathrm{PPh}_{3}\right)_{2}$ points to the fact that the oxidative addition is preceded by another significant process - Pd reduction. Here, to differentiate which one of these processes indeed retards the reaction beginning is impossible. Evidently, these processes are coupled and solution of this problem remains a real challenge.

Based on the obtained results and on the data in literature ${ }^{2,3 a, b}$ the scheme of the Heck reaction catalytic cycle and processes of the catalyst transformation associated with it, can be assumed: 


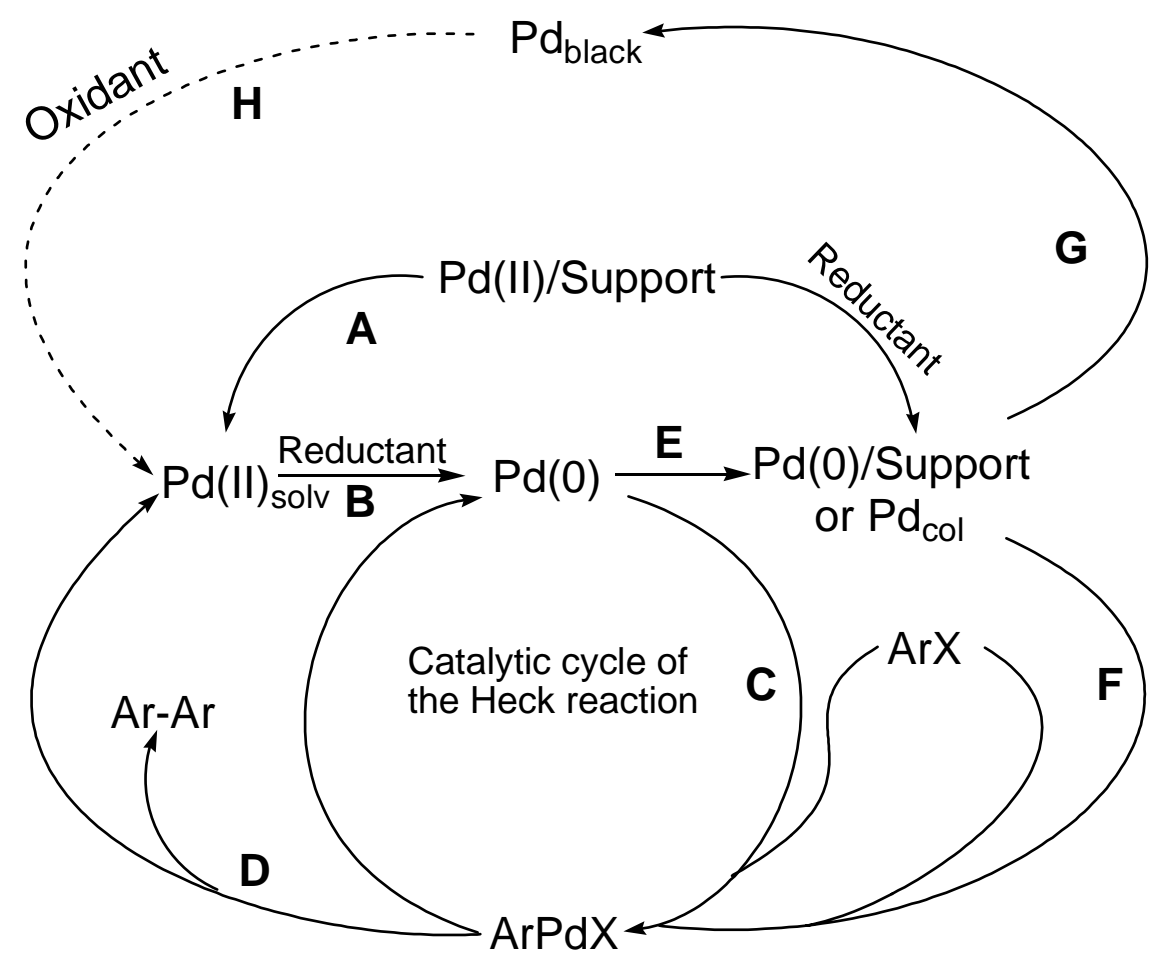

Scheme 4. The simplified key processes of the Heck reaction catalyzed by heterogeneous catalysts.

In the presence of $\mathrm{Pd}(\mathrm{II})$-supported catalyst the first process is $\mathrm{Pd}$ leaching (A); the second reduction of the formed $\operatorname{Pd}(+2)$ to $\operatorname{Pd}(0)$ in the presence of both heterogeneous and homogeneous catalysts $(\mathbf{B})$. The oxidative addition of aryl halide to $\operatorname{Pd}(0)$ complex opens up the catalytic cycle (C). The possible ways of catalyst deactivation during reaction are the oxidation of catalytically active $\mathrm{Pd}$ derived from the side aryl halide transformations $(\mathbf{C}, \mathbf{D})$ and the aggregation $(\mathbf{E}) .{ }^{2 \mathrm{a}}$ The $\operatorname{Pd}(0)$ oxidation can occur as a result of ArX reductive coupling (Scheme 5).

$$
2 \mathrm{ArX}+\mathrm{Pd}(0) \longrightarrow \mathrm{Ar}-\mathrm{Ar}+\mathrm{PdX} 2
$$

Scheme 5. Reductive coupling of ArX

Pd oxidation indicates the necessity of Pd reduction not only at the initial stage but also during the whole reaction. It can be reached by the presence of catalytically quantities of reducing agent in the system. The aggregation of Pd during reaction is a complicated and poorly studied process. The low reactivity of nonactivated aryl halogenides in the stage of oxidative addition favors the catalyst aggregation. In scheme 4 the aggregation is presented by two processes. Using heterogeneous catalyst either Pd deposition may occur on the support with retention of the potential activity due to possible releaching (F) under action of oxidizing agent (aryl halide for example) or $\mathrm{Pd}_{\text {black }}$ formation $(\mathbf{G})$ takes place outside the support with the loss of catalytic properties completely. The latter is valid for homogeneous catalyst as well. But the results currently obtained are indicative of the possibility of reactivation the catalyst being attained due to employment of powerful oxidizer at the end of the reaction $(\mathbf{H}) .{ }^{10}$ In all cases the aggregation is presumed to proceed through the stage 
of colloidal particle formation. Although the colloidal Pd has been found in the Heck reaction there are no compelling evidences of its catalytically activity. ${ }^{2 a, 11}$ But some authors consider the colloidal $\mathrm{Pd}$ as plausible reservoir for the $\operatorname{Pd}(0)$ regeneration in the solution. ${ }^{1 \mathrm{a}, \mathrm{b}, \mathrm{d}}$

The above scheme of the catalyst deactivation-regeneration makes it possible to suggest a number of methods for enhancement of the catalytic system efficiency: the application of catalytic quantities of reducing agent for the Pd recovery from nonactive oxidated state; ${ }^{9}$ an increase of aryl halogenide concentration for the more successful competition of the oxidative addition with the aggregation and for Pd recovery into catalytic cycle from a possible colloidal state, ${ }^{2 a, 11 b, d}$ a decrease of catalyst concentration ${ }^{11,12 a}$ to build up an added barrier to the catalyst agglomeration, which is of the higher kinetic order relative to $\operatorname{Pd}(0)$ than the oxidative addition; ${ }^{12 \mathrm{~b}}$ the use of oxidizing agent for the oxidation of "dead" $\operatorname{Pd}(0)$ agglomerates to a state from which Pd could be involved in catalysis again. $3,10,13$

All discussed processes are connected with the Pd oxidation-reduction transformation. At first sight, the contradictory and intricate data on the use of oxidizers and reducers alternately do not allow to make a conclusion on the nature of processes taking place in the Heck reaction. However, as clear from the scheme, there are reasons for all of suggested approaches where the effective progress of the processes in the system demands the presence of both oxidizing and reducing agents simultaneously.

\section{Catalytic experiments}

Here, we made an effort to put into use above approaches. In the literature an effective catalyst for the Heck reaction with aryl chlorides has been suggested. ${ }^{3 a, b}$ The usage of as little as 0,1 mol\% of $\mathrm{Pd}(\mathrm{II}) / \mathrm{NaY}$ allowed to reach a high chlorobenzene conversion without phosphane ligands. The best results were attained when reaction was performed under an oxygen atmosphere. But it required the temperature raise to $160{ }^{\circ} \mathrm{C}$ and conversion having been high (about 80\%) was not complete. Our results of studies of the reaction between chlorobenzene and styrene are presented in Table 1.

As shown, when the temperature is reduced from $160{ }^{\circ} \mathrm{C}$ (as in Figure1c) to $140{ }^{\circ} \mathrm{C}$ the reaction does not proceed (Entry 1). The presence of sodium formate (Entry 2) allows affording stilbene in moderate yield, whereas the use of two-fold excess of chlorobenzene and sodium formate simultaneously gives rise to full conversion of the initial styrene (Entry 4). When catalytic qualities of the sodium formate and the aryl halide excess are present in system, the positive effect is observed using even as little as $0,01 \mathrm{~mol} \%$ of catalyst (Entry 5). Curiously, the performance of the Heck reaction under an oxygen atmosphere as in literature ${ }^{3 a, b}$ does not produce good result; on the contrary, a very low conversion has been observed. It may well be for the reason that the catalytic oxidation of sodium formate by the air oxygen in the presence of $\mathrm{Pd}(\mathrm{II})$ complexes occurs similar to that in the Heck reaction with aryl iodides. ${ }^{12 b}$ Formally, proposed above system (Entry 4) indeed creates conditions when there are both reducer for $\mathrm{Pd}(\mathrm{HCOONa})$ and oxidizer since the aryl halide excess plays the role of Pd oxidizer (see Scheme 4). 
Table 1. Heck coupling of chlorobenzene with styrene catalyzed by $\mathrm{Pd}(\mathrm{II}) / \mathrm{NaY}$

\begin{tabular}{ccccccc}
\hline Entry & $\begin{array}{c}\text { Catalyst Concentration } \\
{[\mathrm{mol} \%]}\end{array}$ & $\mathrm{PhCl} /$ styrene & NaHCOO/Pd & Time [h] & $\begin{array}{c}\text { Yield } \\
\text { trans- } \\
\text { stilbene[\%] }\end{array}$ & $\begin{array}{c}\text { Yield } \\
\text { benzene } \\
{[\%]}\end{array}$ \\
\hline 1 & 0.1 & $1: 1$ & --- & 7 & 0 & 2 \\
2 & 0.1 & $1: 1$ & 17 & 7 & 16 & 4 \\
3 & 0.1 & $2: 1$ & --- & 7 & 0 & 4 \\
4 & 0.1 & $2: 1$ & 17 & 7 & 96 & 8 \\
5 & 0.01 & $2: 1$ & 17 & 24 & 69 & 7 \\
\hline
\end{tabular}

Conditions: $\mathrm{Ca}(\mathrm{OH})_{2}, \mathrm{NBu}_{4} \mathrm{Br}$, air, $140{ }^{\circ} \mathrm{C}$.

The high activity of homogeneous "ligand-free" catalyst $\left(\mathrm{Pd}(\mathrm{OAc})_{2}\right.$ or $\left.\mathrm{PdCl}_{2}\right)$ in the Heck reaction with arylbromides has been already demonstrated. ${ }^{11}$ Negligible amounts of Pd salts and/or the excess of arylbromides allowed to reach the high conversion. Unfortunately, such an approach was not successful for aryl chlorides. The use of our approach for the reaction of chlorobenzene with styrene (i.e. application of the chlorobenzene excess, catalytic quantities of reducing agent and $\mathrm{Pd}$ low concentration simultaneously) has first provided the sufficiently high yield of stilbene in the presence of ligand-free homogeneous catalyst at $140{ }^{\circ} \mathrm{C}$ (see Table 2).

Table 2. Heck coupling of $\mathrm{PhX}$ with styrene catalyzed by $\mathrm{PdCl}_{2}$

\begin{tabular}{ccccccc}
\hline Entry & $\mathrm{PhX}$ & $\mathrm{PhX} /$ styrene & NaHCOO/Pd & Time [h] & $\begin{array}{c}\text { Yield } \\
\text { trans- } \\
\text { stilbene[\%] }\end{array}$ & $\begin{array}{c}\text { Yield } \\
\text { benzene } \\
{[\%]}\end{array}$ \\
\hline 1 & $\mathrm{PhBr}$ & $1: 1$ & --- & 5 & 96 & 3 \\
2 & $\mathrm{PhCl}$ & $1: 1$ & 9 & 17 & 10 & 4 \\
3 & $\mathrm{PhCl}$ & $2: 1$ & --- & 17 & 19 & 5.5 \\
4 & $\mathrm{PhCl}$ & $2: 1$ & 9 & 17 & 52 & 6 \\
5 & $\mathrm{PhCl}$ & $3: 1$ & 9 & 17 & 71 & 7 \\
6 & $\mathrm{PhCl}$ & $4: 1$ & 9 & 17 & 75 & 8.5 \\
\hline
\end{tabular}

Conditions: $\mathrm{Ca}(\mathrm{OH})_{2}, \mathrm{NBu}_{4} \mathrm{Br}, 0.1 \mathrm{~mol} \% \mathrm{PdCl}_{2}$, air.

\section{Conclusions}

It has been established that Pd leaching from catalyst surface initiates progress of the catalytic reaction. That conclusion is based on the data from NMR monitoring and GLC analysis indicating that an appearance of the oxidative addition product in the solution and the beginning of the catalytic reaction occur simultaneously. The possible ways of the catalyst deactivation during reaction are the oxidation of catalytically active $\mathrm{Pd}$ (accompanied by formation of $\left[\mathrm{PdX}_{2}\left(\mathrm{PPh}_{3}\right)_{2}\right]$ ) 
derived from the side aryl halide transformation and $\operatorname{Pd}(0)$ aggregation. The data obtained allowed us to propose a number of the simple methods (which affect the ratio of the active catalyst formation - deactivation rates) for enhancement of the catalyst activity in the reactions with unreactive aryl halides. The results of the performed experiments have shown that the simultaneous usage of reducing agent and the excess of aryl halides affords the quantitative yield of the product and the lowering of the temperature in the Heck reaction with chlorobenzene without utilization of any ligands in an inert atmosphere. The same results have first been reached in the presence of homogeneous precursors.

\section{Experimental Section}

General. All reagents and solvents were obtained from Aldrich/Fluka or Merck (grade p.a.). ${ }^{31} \mathrm{P}$ NMR spectra were recorded with a Bruker AM 400 spectrometer; the chemical shifts were given with respect to the signal of $85 \% \mathrm{H}_{3} \mathrm{PO}_{4}$. In situ NMR monitoring of the Heck reaction was carried out in J. Young's NMR pressure tubes. The mixture was heated starting at room temperature and ${ }^{31} \mathrm{P}$ NMR spectra were taken at $70,90,110{ }^{\circ} \mathrm{C}$ and further at $140{ }^{\circ} \mathrm{C}$ every 20 min. 1 wt.\% $\mathrm{Pd}(\mathrm{II}) / \mathrm{NaY}$ zeolite and 3 wt. $\% \mathrm{Pd}(\mathrm{II}) / \mathrm{Al}_{2} \mathrm{O}_{3}$ were synthesized according to the literature. ${ }^{3,13}$

\section{Preparation of $\mathrm{Pd}(\mathrm{X})(\mathrm{Ph})\left(\mathrm{PPh}_{3}\right)_{2}$ complexes starting from $\mathrm{Pd}(\mathrm{II})$ precursors}

All preparations, manipulations and reactions of palladium phosphine complexes were carried out under argon atmosphere. All complexes were prepared by analogy with the known procedures. ${ }^{6 a, 8 a}$ For the preparation of $\mathrm{Pd}(\mathrm{X})(\mathrm{Ph})\left(\mathrm{PPh}_{3}\right)_{2}(\mathrm{X}=\mathrm{Cl}, \mathrm{Br}$, OAc), $10 \mathrm{mmol}$ of $\mathrm{PhI}$ and $0.3 \mathrm{mmol}$ of a reducing agent $\left(\mathrm{NBu}_{3}\right)$ were added to $10 \mathrm{ml}$ of an $\mathrm{N}$-methylpyrrolidone (NMP) solution containing $0.1 \mathrm{mmol}$ of $\mathrm{Pd}\left(\mathrm{X}_{2}\right)\left(\mathrm{PPh}_{3}\right)_{2}$. The reaction mixture was stirred at $70{ }^{\circ} \mathrm{C}$ until the signal of initial $\mathrm{Pd}\left(\mathrm{X}_{2}\right)\left(\mathrm{PPh}_{3}\right)_{2}$ completely disappeared ( 60 min) and a signal corresponding to $\mathrm{Pd}(\mathrm{X})(\mathrm{Ph})\left(\mathrm{PPh}_{3}\right)_{2}$ $(\mathrm{X}=\mathrm{Cl}, \mathrm{Br}, \mathrm{OAc})$ appeared (Scheme 3$)$.

\section{Catalytic test reactions}

The catalytic reactions were performed on a Radley's 12-placed Carousel Reaction Station ${ }^{\mathrm{TM}}$ equipped with gas tight threaded caps with valve, cooling reflux head system and a fuzzy logic controller unit giving temperature control to $0.1{ }^{\circ} \mathrm{C} .10 \mathrm{mmol}$ of aryl halide, $10 \mathrm{mmol}$ of styrene, 12 mmol of base, $6 \mathrm{mmol} \mathrm{NBu} 4 \mathrm{Br}$ (for reaction with $\mathrm{PhCl}$ ) and 0.01-0.5 mol\% of [Pd] were introduced to a reaction tube under an air. $10 \mathrm{~mL}$ of solvent (NMP) were added and the tube was then placed in a pre-heated reaction station at $140{ }^{\circ} \mathrm{C}$. In some experiments, the reaction was carried out in the presence of $\mathrm{PPh}_{3}$ (2 eq. to [Pd]) under argon atmosphere. Filtered samples were extracted with water $/ \mathrm{CH}_{2} \mathrm{Cl}_{2}$ and dried over $\mathrm{MgSO}_{4}$. Products were identified by Gas Liquid Chromatography (GLC). Conversion and yields were quantified by GLC (HP-6890 chromatograph, cross-linked methylsiloxane, $30 \mathrm{~m} \times 0.25 \mathrm{~mm} \times 0.25 \mu \mathrm{m}$ film thickness, flame-ionization detector) using diethylene glycol dibutylether as internal standard $(\Delta \mathrm{rel}= \pm 5 \%)$. 


\section{Pd leaching tests during the reaction}

Bromobenzene (180 mmol), styrene (270 mmol), NaOAc (216 mmol), NMP (200 mL), $\mathrm{Pd} / \mathrm{Al}_{2} \mathrm{O}_{3}$ catalyst $(0.2 \mathrm{~mol} \%)$ and $\mathrm{PPh}_{3}$ (when added $0,36 \mathrm{mmol}$ ) were heated to $140{ }^{\circ} \mathrm{C}$ in a round bottom flask. After defined reaction times an aliquot of the reaction mixture was removed. For palladium leaching the filtered sample $(5 \mathrm{~mL})$ was evaporated and the palladium content of the residue was analyzed by flame atomic absorption spectroscopy (AAS).

\section{Acknowledgements}

A.F. Schmidt and V.V. Smirnov thank the German Service for Academic Exchanges (DAAD) and Federal Agency for Education of Russian Federation (GK N P1344)

\section{References}

1. (a) Heck, R. F.; Palladium Reagents in Organic Synthesis, VCH: Weinheim, 1996. (b) Beletskaya, I. P.; Cheprakov, A. V. Chem. Rev. 2000, 100, 3009. (c) Whitcombe, N. J.; Hii, K. K.; Gibson, S. E. Tetrahedron 2001, 57, 7449. (d) Alonso, F.; Beletskaya, I. P.; Yus, M. Tetrahedron 2005, 61, 11771. (e) Farina, V. Adv. Synth. Catal. 2004, 346, 1553. (f) Phan, N. T. S.; Van Der Sluys, M.; Jones, C. W. Adv. Synth. Catal. 2006, 348, 609. (g) J. G. de Vries, Dalton Trans. 2006, 421. (h) Wu, X. F.; Anbarasan, P.; Neumann, H.; Beller, M. Angew. Chem. Int. Ed. 2010, 49, 9047. (i) Astruc, D., Inorganic Chemistry. 2007, 46, 1884. (j) Karimi, B.; Behzadnia, H.; Elhamifar, D.; Akhavan, P. F.; Esfahani, F. K.; Zamani, A. Synthesis 2010, 9, 1399. (k) Bellina, F.; Chiappe, C. Molecules 2010, 15, 2211.

2. (a) Schmidt, A. F.; Al Halaiqa, A; Smirnov, V. V. Synlett. 2006, 18, 2861. (b) Köhler, K.; Pröck1, S. S.; Kleist, W. Current Organic Chemistry 2006, 10, 1585. (c) Kohler, K.; Kleist, W.; Prockl, S. S., Inorg. Chem. 2007, 46, 1876.

3. (a) Pröckl, S. S.; Kleist, W.; Gruber, M. A.; Köhler, K. Angew. Chem. Int. Ed. 2004, 43, 1881.

(b) Pröckl, S.S.; Kleist, W.; Köhler, K. Tetrahedron. 2005. 61. 9855. (c) Martra, G.; Bertinetti, L.; Gerbaldi, C.; Maggi, R.; Sartori, G.; Coluccia, S., Catal. Lett. 2009, 132, 50. (d) Marc, L.; Luma, N.-H.; Jean-Cyrille, H.; Eric, F.; Franzois-Xavier, F., Adv. Synth. Catal. 2010, 352, 33.

4. Heck R. F.; Nolley J. P. J. Org. Chem. 1972, 37, 2320.

5. (a) Shmidt, A. F.; Mametova, L. V. Kinet .Catal. 1996, 37, 406. (b) Köhler, K.; Heidenreich, R. G.; Krauter, J. G. E.; Pietsch, J. Chem. Eur. J. 2002, 8, 622. (c) Biffis, A.; Zecca, M.; Basato, M. J. Mol. Catal. A: Chemical 2001, 173, 249. (d) Zhao, F.; Shirai, M.; Arai, M. J. Mol. Catal. A: Chemical 2000, 154, 39. (e) Gaikwad, A. V.; Holuigue, A.; Thathagar, M. B.; ten Elshof, J. E.; Rothenberg, G., Chem. Eur. J. 2007, 13, 6908.

6. (a) Shmidt, A. F.; Smirnov, V. V. Kinet. Catal. 2002, 2, 215. (b) Jutand, A.; Negri, S.; de Vries, J. G. Eur. J. Inorg. Chem. 2002, 7, 1711. 
7. (a) Brown, J. M.; Hii, K. K. Angew. Chem., Int. Ed. Engl. 1996, 35, 657. (b) Ludwig, M.; Stromberg, S.; Svensson, M.; Akermak, B. Organometallics 1999, 18, 970. (c) Amatore, C.; Carre, E.; Jutand, A. Organometallics 1995, 14, 5605. (d) Amatore, C.; Carre, E.; Jutand, A.; Medjour, Y. Organometallics 2002, 21, 4540.

8. (a) Shmidt, A. F.; Smirnov, V. V. Kinet. Catal. 2005, 4, 529. (b) Ren, G.; Cui, X.; Yang, E.; Yang, F.; Wu, Y., Tetrahedron 2010, 66, 4022.

9. Schmidt, A. F.; Halaiqa, A.; Nindakova, L. O.; Skripina, O. S. React. Kinet. Catal. Lett. 1999, $67,301$.

10. de Vries, A. H. M.; Parlevliet, F. J.; Schmieder-van de Vondervoort, L.; Mommers, J. H. M.; Henderickx, H. J. W.; Walet, M. A. N.; de Vries, J. G. Adv. Synth. Catal. 2002, 344, 996.

11. (a) de Vries, A. H. M.; Mulders, J. M. C. A.; Mommers, J. H. M.; Henderickx, H. J. W.; de Vries, J. G. Org. Lett. 2003, 5, 3285. (b) Schmidt, A. F.; Smirnov, V. V. J. Mol. Catal. A: Chemical 2003, 203, 75. (c) Yao, Q.; Kinney, E. P.; Yang, Z. Org. Chem. 2003, 68, 7528. (d) Schmidt, A. F.; Al-Halaiqa, A.; Smirnov, V. V. J. Mol. Catal. A: Chemical 2006, 250, 131.

12. (a) Schmidt, A. F.; Smirnov V. V. Top. Catal. 2005, 32, 71. (b) Shmidt, A.; Khalaika, A. Kinet. Catal. 1998, 6, 803.

13. Djakovitch, L.; Köhler, K. J. Am. Chem. Soc. 2001, 123, 5990. 